Article

\title{
Investigation of Microwave Ablation Process in Sweet Potatoes as Substitute Liver
}

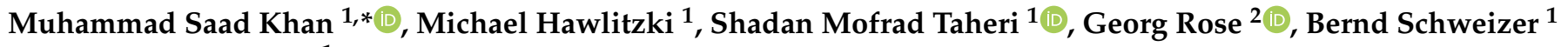 \\ and Andreas Brensing ${ }^{1}$
}

1 Department of Engineering, RheinMain University of Applied Sciences, 65428 Ruesselsheim, Germany; michael@hawlitzki.com (M.H.); shadan.taheri@hotmail.com (S.M.T.); bernd.schweizer@hs-rm.de (B.S.); andreas.brensing@hs-rm.de (A.B.)

2 Institute of Medical Engineering and Research Campus STIMULATE, Otto Von Guericke University, 39106 Magdeburg, Germany; georg.rose@ovgu.de

* Correspondence: muhammadsaad.khan@hs-rm.de

Citation: Khan, M.S.; Hawlitzki, M.; Taheri, S.M.; Rose, G.; Schweizer, B.; Brensing, A. Investigation of Microwave Ablation Process in Sweet Potatoes as Substitute Liver. Sensors 2021, 21, 3894. https://doi.org/ $10.3390 / \mathrm{s} 21113894$

Academic Editor: Ki H. Chon

Received: 7 May 2021

Accepted: 31 May 2021

Published: 4 June 2021

Publisher's Note: MDPI stays neutral with regard to jurisdictional claims in published maps and institutional affiliations.

Copyright: (c) 2021 by the authors. Licensee MDPI, Basel, Switzerland. This article is an open access article distributed under the terms and conditions of the Creative Commons Attribution (CC BY) license (https:// creativecommons.org/licenses/by/ $4.0 /)$.
Abstract: The microwave ablation technique to destroy cancer tissues in liver is practiced clinically and is the subject of ongoing research, e.g., ablation monitoring. For studies, liver tissue from cattle or pigs is often used as a substitute material. In this work, sweet potato is presented as an alternative material for microwave ablation experiments in liver due to similar material properties. Sweet potatoes as a substitute for liver have the advantages of better handling, easy procurement and stable material properties over time for microwave ablation experiments. The dielectric constant and electrical conductivity of sweet potato are characterized for temperature variation with the help of high-temperature dielectric probe. Furthermore, a test setup is presented for microwave ablation experiments in which a bowtie slot antenna matched to sweet potato is placed on its surface to directly receive the microwave power from a self-developed microwave applicator inserted into a sweet potato $4 \mathrm{~cm}$ below the surface antenna. A high-power source was used to excite the microwave powers up to $80 \mathrm{~W}$ and a spectrum analyzer was used to measure the signal received by the surface antenna. The experiments were performed in an anechoic chamber for safety reasons. Power at $50 \mathrm{~W}$ and $80 \mathrm{~W}$ was stimulated for a maximum of $600 \mathrm{~s}$ at the $2.45 \mathrm{GHz}$ ISM band in different sweet potato experiments. A correlation is found between the power received by the surface antenna and rise of temperature inside sweet potato; relative received power drops from 1 at $76{ }^{\circ} \mathrm{C}$ to 0.6 at $88^{\circ} \mathrm{C}$ (max. temperature) represents a $40 \%$ relative change in a $50 \mathrm{~W}$ microwave ablation experiment. The received power envelope at the surface antenna is between $10 \mathrm{~mW}$ and $32 \mathrm{~mW}$ during $50 \mathrm{~W}$ microwave ablation. Other important results for $10 \mathrm{~min}, 80 \mathrm{~W}$ microwave ablation include: a maximum ablation zone short axis diameter of $4.5 \mathrm{~cm}$ and a maximum ablation temperature reached at $99{ }^{\circ} \mathrm{C}, 3 \mathrm{~mm}$ away from the applicator's slot. The results are compared with the state of the art in microwave ablation in animal liver. The dielectric constant and electrical conductivity evolution of sweet potato with rising temperature is comparable to animal liver in $50-60{ }^{\circ} \mathrm{C}$ range. The reflection loss of self-developed applicator in sweet potato is below $15 \mathrm{~dB}$ which is equal to reflection loss in liver experiments for $600 \mathrm{~s}$. The temperature rise for the first $90 \mathrm{~s}$ in sweet potato is $76{ }^{\circ} \mathrm{C}$ as compared to $73{ }^{\circ} \mathrm{C}$ in liver with $50 \mathrm{~W}$ microwave ablation. Similarly, with $80-75 \mathrm{~W}$ microwave ablation, for the first $60 \mathrm{~s}$, the temperature is $98^{\circ} \mathrm{C}$ in sweet potato as compared to $100{ }^{\circ} \mathrm{C}$ in liver. The ablation zone short-axis diameter after $600 \mathrm{~s}$ is $3.3 \mathrm{~cm}$ for $50 \mathrm{~W}$ microwave ablation in sweet potato as compared to $3.5 \mathrm{~cm}$ for $30 \mathrm{~W}$ microwave ablation in liver. The reasons for difference in microwave ablation results in sweet potato and animal liver are discussed. This is the first study to directly receive a signal from microwave applicator during a microwave ablation process with the help of a surface antenna. The work can be extended to multiple array antennas for microwave ablation monitoring.

Keywords: liver; microwave ablation; sweet potato; temperature monitoring 


\section{Introduction}

Liver cancer is the seventh most likely and the second most deadly cause of cancers worldwide; in 2018, mortality rate was $93 \%$ out of total new cases reported [1], while in another reference, a 20\% 5-year relative survival rate was reported [2]. Thus, the early detection and rapid treatment of liver cancer is crucial. Hyperthermia [3] and microwave hyperthermia [4] were proposed as early as 1980 for the treatment of different cancers in the human body. Some recent applications of hyperthermia have been in cardiac ablation [5], in the enhancement of low-density lipoprotein (LDL) transport in arteries [6], and in drug delivery enhancement [7-9]. Thermal ablative techniques to destroy liver and other cancer tissue cells using laser, radio frequency (RF) and microwaves has been practiced clinically for the past two decades $[10,11]$. However, microwave ablation (MWA) outshines the others as an effective treatment due to the advantages it offers of ablating comparatively large tissue in a smaller amount of time as compared to RF and laser ablation [12].

Furthermore, monitoring the growth of the ablation zone during a MWA is a current research problem which is related to the safety of the tissues and organs close to the infected area. Many approaches are being investigated to tackle this problem; some of which are invasive like temperature monitoring using fiber Bragg grating sensors $[13,14]$ and using localized probes at the tip of the microwave applicator [15]. However, invasive approaches give localized information at a point or along a line, insufficient for the temperature mapping of the ablation zone. Additionally, deploying and locating these sensors is also a challenge. Magnetic resonance imaging (MRI)-based thermometry is a non-invasive technique for temperature monitoring during MWA but then the complete intervention has to be performed inside an MRI scanner [16,17]. Hence, microwave imaging using body matched antennas (BMAs) is experimented as an independent non-invasive technique for real-time imaging and monitoring the thermal ablation process [18,19]; however, in [18], an array of ultra-wideband (UWB) antennas is used in a bistatic radar principle to carry out the reconstruction. Another simpler approach for carrying out microwave imaging by using a microwave applicator as a transmit antenna and a surface BMA as a receiving antenna at $2.45 \mathrm{GHz}$ was suggested in [20] by the authors.

For understanding MWA in liver, experimental studies are performed on animal liver to record localized temperature, temperature dispersive material properties and the spread of the ablation zone with ablation time and power. However, the material properties of an ex-vivo liver are highly instable, as with increasing time after the slaughter, the animal liver rapidly loses water and its electrical conductivity also changes. Therefore, there is a need for a substitute material for experimental studies for monitoring of MWA in liver. The primary goal of this work is to present sweet potatoes (SPs) as a substitute material for MWA experiments on liver and the rationale for doing so are the similar material properties of SP and liver. The properties of SPs, as reported in [21], motivated the authors to explore SPs as alternative to liver due to similar dielectric constant and electrical conductivity. Table 1 shows the comparison of dielectric constant, electrical conductivity, water content and the density of liver and SP at room temperature at $2.45 \mathrm{GHz}$. All the properties are very similar to each other and the maximum difference between any property is $19 \%$ as in case of the dielectric constant.

Table 1. Material properties of liver and SP at $2.45 \mathrm{GHz}$ at room temperature.

\begin{tabular}{ccc}
\hline Property & Liver & SP \\
\hline Density & $0.95 \mathrm{~g} / \mathrm{cm}^{3}[22]$ & $1.07 \mathrm{~g} / \mathrm{cm}^{3}[21]$ \\
Water content & $80.5 \%[23]$ & $75 \%[21]$ \\
Dielectric constant $\left(\epsilon_{r}\right)$ & $43[24]$ & $52[21]$ \\
Electrical conductivity $(\sigma)$ & $1.7 \mathrm{~S} / \mathrm{m}[24]$ & $1.9 \mathrm{~S} / \mathrm{m}[21]$ \\
\hline
\end{tabular}

In addition to having similar material properties, there are also other advantages for using SPs instead of animal liver for MWA experiments. Firstly, SPs are easier to handle than animal liver because there is no blood involved during the experiments which needs 
proper handling. Also from a logistic point of view, a raw animal liver cannot be stored for long even with cooling while SPs are easy to procure. Secondly, the properties of SPs are more stable over time, which in case of a slaughtered animal liver, drastically change due to the loss of moisture content which is $70-80 \%$ of the total liver meat volume [23]. Additionally, during an ex-vivo MWA, when the inner part of the liver is ablated, the outer liver does not give the same liver properties as one would expect in an in-vivo environment. On the other hand, in SPs the properties of the outer part remain the same during a MWA experiment.

Furthermore, in this paper, a system for carrying out MWA experiments is presented. This system is useful for measuring temperature development during ablation process, ablation zone short axis diameter (SAD), testing new microwave applicator designs and microwave field distribution for use in a monitoring system with the help of BMAs. A self-developed microwave applicator and a similar bow-tie BMA [20] are used during the course of experiments.

\section{Materials and Methods}

A microwave applicator, BMA, high-power RF source, anechoic chamber, fiber optic temperature sensor, spectrum and vector network analyzers were used for the experimental work. The block diagram of the MWA experiments is shown in Figure 1.

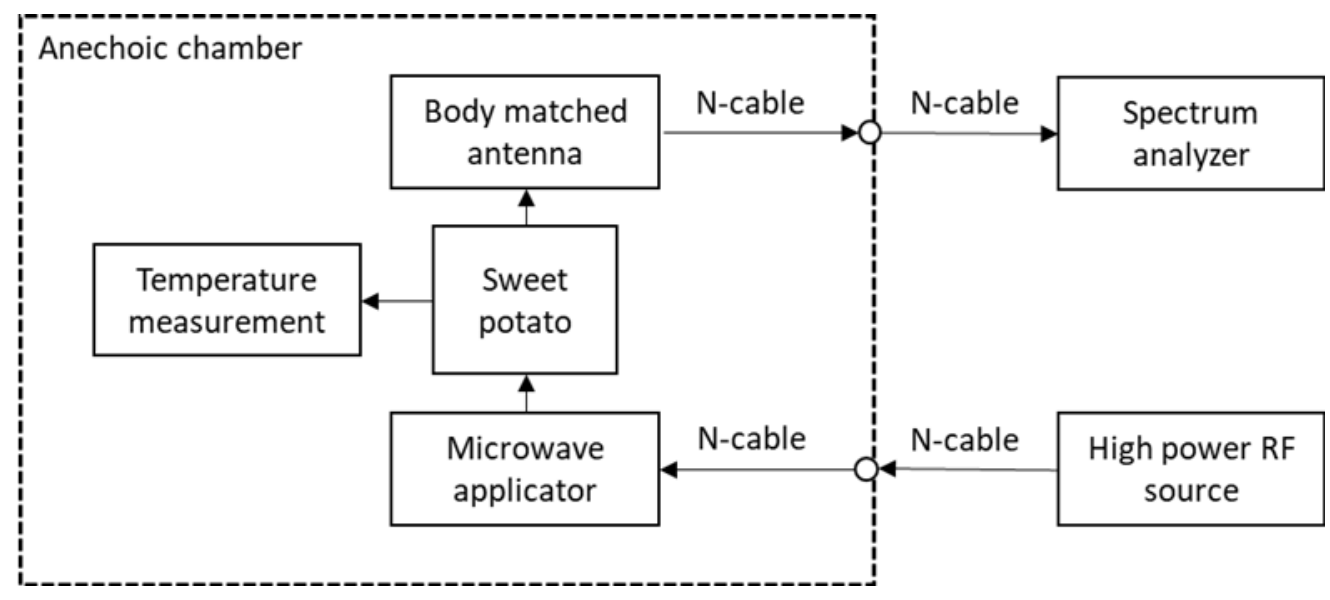

Figure 1. MWA experiment flowchart.

A self-developed microwave applicator with a slot $(15 \mathrm{~mm})$ before the tip was used for exciting 50-80 W microwave power in SP at $2.45 \mathrm{GHz}$. A commercial applicator offered by COVIDIEN $[25,26]$ was also used to benchmark the self-developed applicator. The received antenna used is a similar bowtie-slot microstrip patch BMA with an edge-fed SubMiniature version-A (SMA) connection designed for 2.2-2.8 GHz [20]. A Kuhne electronic signal generator (KU SG 2.45-250 A) controlled by a graphical user interface (GUI) was used to excite high power for MWA [27]. The power can be varied from 10 to $250 \mathrm{~W}$, in increments of $10 \mathrm{~W}$. The operational frequency band was from 2.4 to $2.5 \mathrm{GHz}$, which can be changed in the $0.05 \mathrm{GHz}$ steps. The reflected as well as the excited power can be monitored in the GUI. Since the experiments involve high-power microwave radiations, the microwave applicator inserted into the SP along with the receiving BMA were placed in the anechoic chamber at the HF Lab in RheinMain University of Applied Sciences. For the temperature measurement, a fiber optic temperature sensor of the LumaSense technologies of the $\mathrm{m} 920$ series was used [28]. The $3 \mathrm{~mm}$ tip of the (STF) probe was sensitive to the temperature changes from 0 to $295^{\circ} \mathrm{C}$ with a response time of $0.25 \mathrm{~s}$. The spectrum analyzer from Rigol (RSA3045) with a frequency range from $9 \mathrm{kHz}$ to $4.5 \mathrm{GHz}$ and dynamic range between $-50 \mathrm{dBm}$ and $+30 \mathrm{dBm}$ was used to record the received antenna power during the experiments [29]. The reflection losses $\left(S_{11}, S_{22}\right)$ of the microwave applicators and the BMA and the insertion loss $\left(S_{21}\right)$ were measured with a two-port vector network analyzer 
(VNA) from Rohde and Schwarz (R\&S®ZVL13) [30]. The experimental setup discussed above is shown in Figure 2.

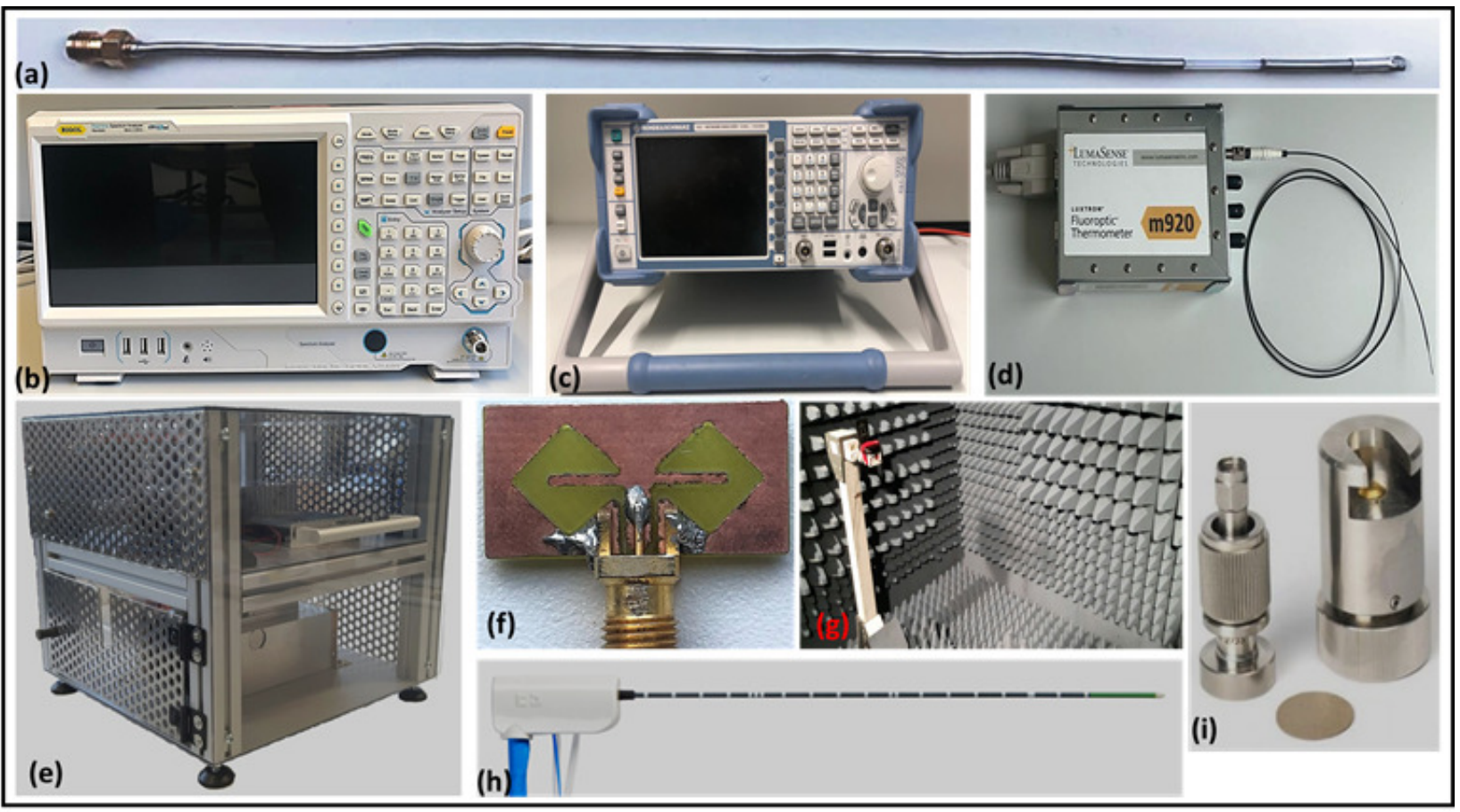

Figure 2. MWA experimental setup: (a) self-developed microwave applicator with a single slot; (b) spectrum analyzer; (c) VNA ; (d) LumaSense temperature probe; (e) high-power RF source; (f) BMA; (g) anechoic chamber; (h) Covidien Emprint $^{\mathrm{TM}}$ Standard Percutaneous Antenna with Thermosphere ${ }^{\mathrm{TM}}$ Technology; (i) N1501A high-temperature probe kit.

The block diagram of the measurement of network loss is shown in Figure 3. To determine the network loss due to $\mathrm{N}$-cables and adapters, a transmission measurement was performed. A signal generator and a spectrum analyzer were connected to the $\mathrm{N}$ connections on the wall of anechoic chamber from outside and then two more $\mathrm{N}$ cables were connected from inside of the chamber which were short circuited to each other through an $\mathrm{N}-\mathrm{N}$ female adapter. An RF attenuator of $30 \mathrm{~dB}$ was used for the protection of the spectrum analyzer in the received path for supplying powers in excess of $+30 \mathrm{dBm}$ which was the max. power rating of the spectrum analyzer. An input power of $10 \mathrm{dBm}$ at $2.45 \mathrm{GHz}$ was supplied from the signal generator and $-25.8 \mathrm{dBm}$ power was received at the spectrum analyzer; thus, a total loss of $35.8 \mathrm{~dB}$ is calculated, which includes the network loss of $5.8 \mathrm{~dB}$.

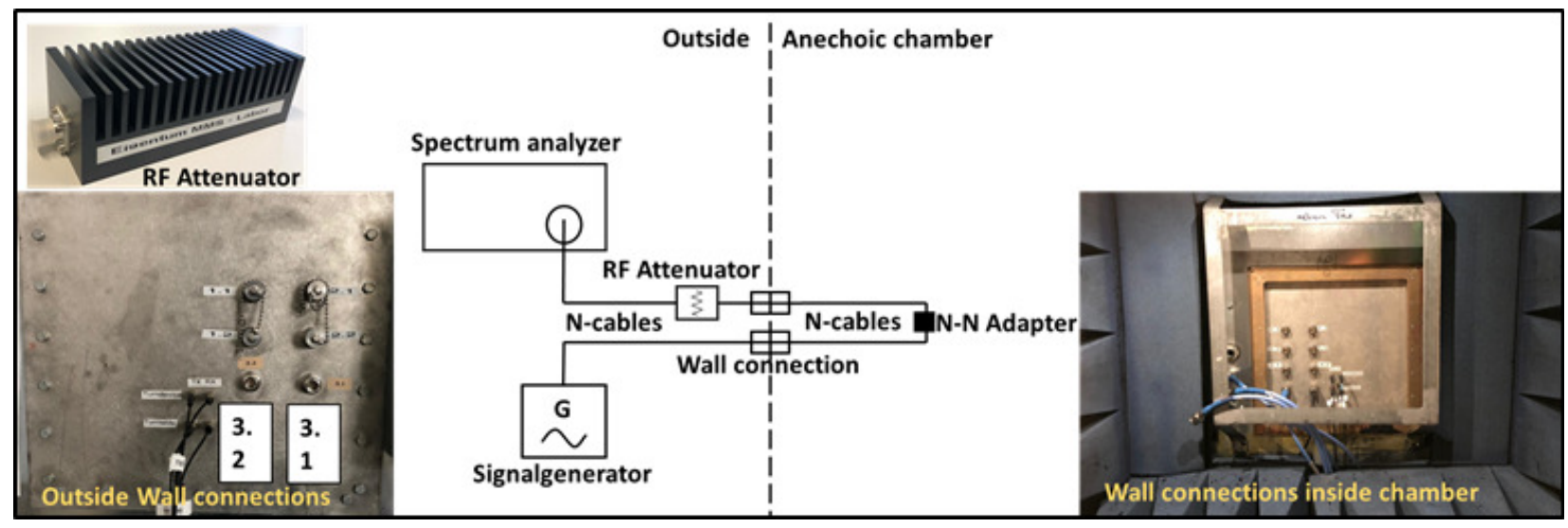

Figure 3. Network loss measurement setup. 
The measurement setup for the SP experiments was first tested with double-distilled water as a medium. A water container, BMA placed on the water surface and microwave applicator dipped $7.5 \mathrm{~cm}$ (distance between the BMA center and the applicator slot) below the water surface, were placed in the anechoic chamber. The BMA and the applicator were connected to the $\mathrm{N}$ connections on the chamber wall. A transmitted power of $47 \mathrm{dBm}$ at $2.45 \mathrm{GHz}$ was supplied and a received signal of $-40.6 \mathrm{dBm}$ was measured. The total power loss was $87.6 \mathrm{~dB}$ and after subtracting the loss of $35.8 \mathrm{~dB}$ due to the attenuator and the network, the attenuation in the double-distilled water was $51.8 \mathrm{~dB}$, which is in good agreement with the simulation value of $51.5 \mathrm{~dB}$. The setup is shown in Figure 4.

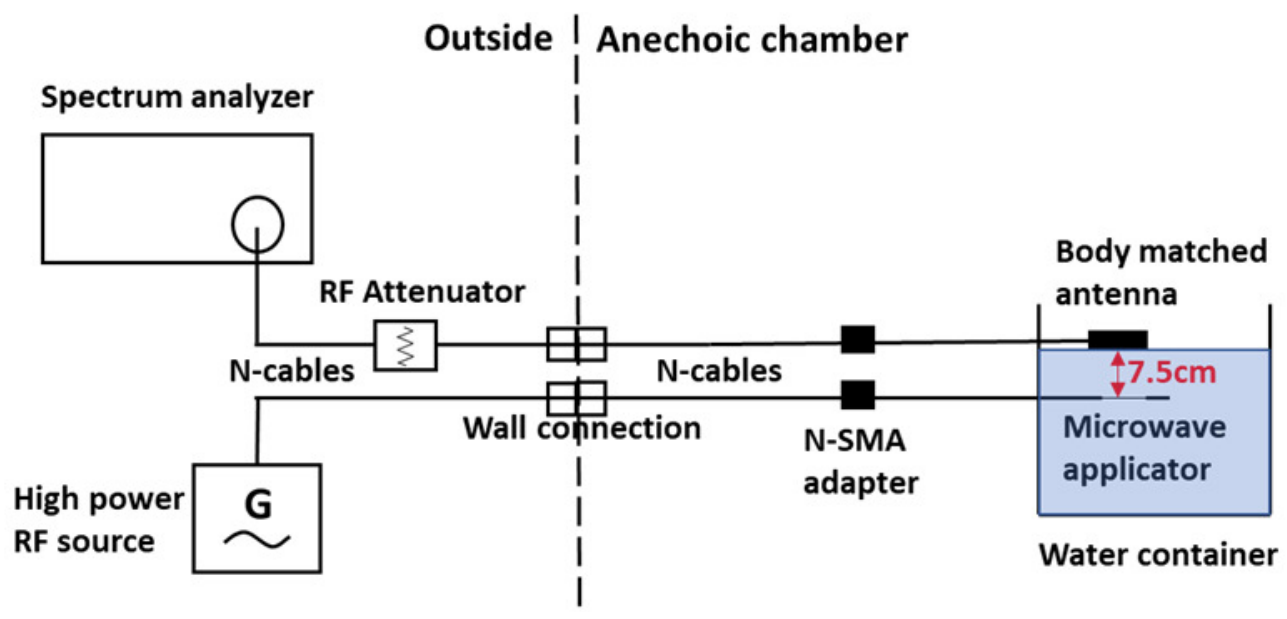

Figure 4. MWA experimental setup testing in water.

It is important to characterize the material properties of SP with respect to temperature. For this purpose, the dielectric and conductive properties of SP were determined by increasing temperature with a heating plate, digital thermometer, high temperature probe [31] and VNA at $2.45 \mathrm{GHz}$. The SP was cut into $1 \mathrm{~cm}$-thick slices and placed on the heating plate. The probe was then placed on the surface of the SP as shown in Figure 5.

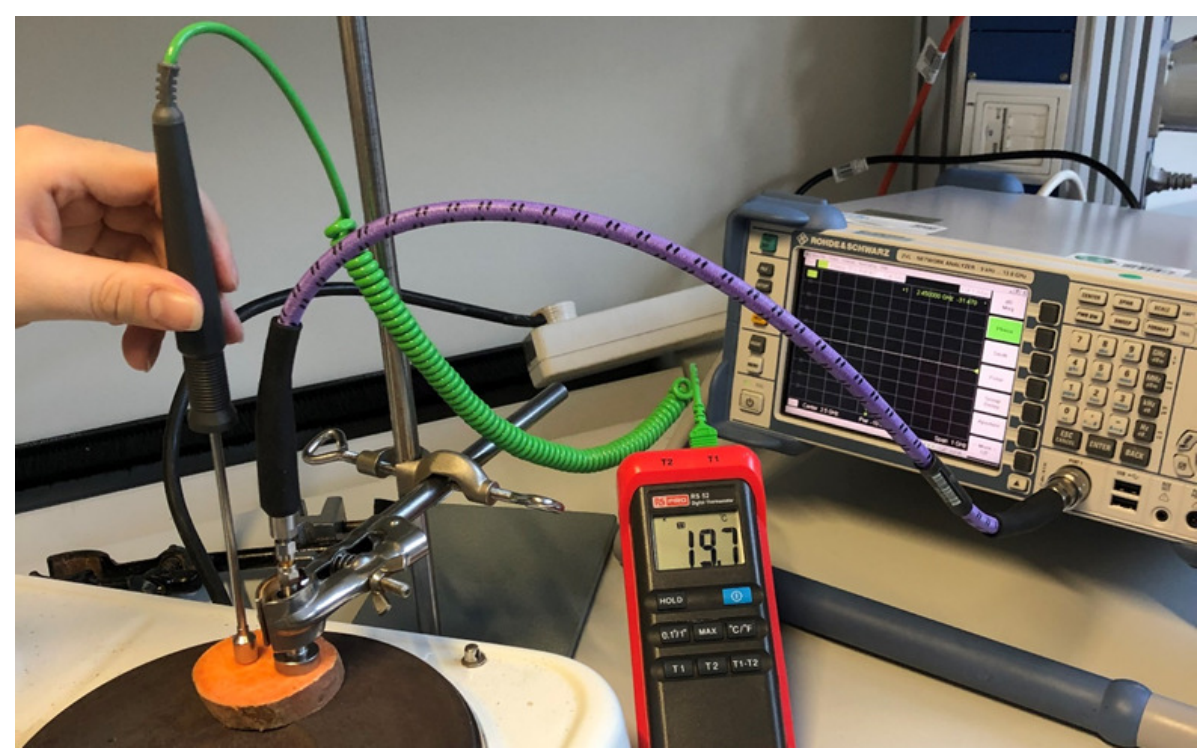

Figure 5. Experimental setup for measuring material properties of SP.

The calculated material properties of the SP are shown in Table 2. The electrical conductivity of the SP decreases from $2.6 \mathrm{~S} / \mathrm{m}$ at room temperature to $2.1 \mathrm{~S} / \mathrm{m}$ at $60{ }^{\circ} \mathrm{C}$. At temperatures above $60^{\circ} \mathrm{C}$, the $\sigma$ increases due to the formation of water between the probe 
and the SP, the $\epsilon_{r}$ shows a similar behavior. The measurement method has an uncertainty of $10 \%$. The evolution of material properties of SP with temperature are compared with the liver below $80^{\circ} \mathrm{C}$ as in [32]. The change in the properties show a similar trend between $\mathrm{SP}$ and the liver. The comparisons of temperature-dependent $\epsilon_{r}$ and $\sigma$ of SP and liver are shown in Figure A1.

Table 2. Temperature-dependent material properties of SP at $2.45 \mathrm{GHz}$.

\begin{tabular}{ccc}
\hline Temperature & Electrical Conductivity $(\sigma)$ & Relative Permittivity $\left(\epsilon_{r}\right)$ \\
\hline $21^{\circ} \mathrm{C}$ & $2.6 \mathrm{~S} / \mathrm{m}$ & 57.5 \\
$39^{\circ} \mathrm{C}$ & $2.2 \mathrm{~S} / \mathrm{m}$ & 55.6 \\
$60^{\circ} \mathrm{C}$ & $2.1 \mathrm{~S} / \mathrm{m}$ & 50.7 \\
$75^{\circ} \mathrm{C}$ & $2.8 \mathrm{~S} / \mathrm{m}$ & 55.1 \\
\hline
\end{tabular}

Figure 6 shows the setup of an MWA experiment of a SP in an anechoic chamber. One end of the SP was cut to place the BMA on the SP surface. The BMA was firmly fixed on the surface with help of rubber bands so that the BMA does not move during the measurements and there is no air gap between the BMA and the surface of SP. The center-to-center distance between the BMA and the applicator's slot is always $4 \mathrm{~cm}$. The hole for inserting the microwave applicator is marked vertically $4 \mathrm{~cm}$ below the SP. The exact position of the applicator and temperature sensor's hole and the hole depth are determined by using a level ruler.
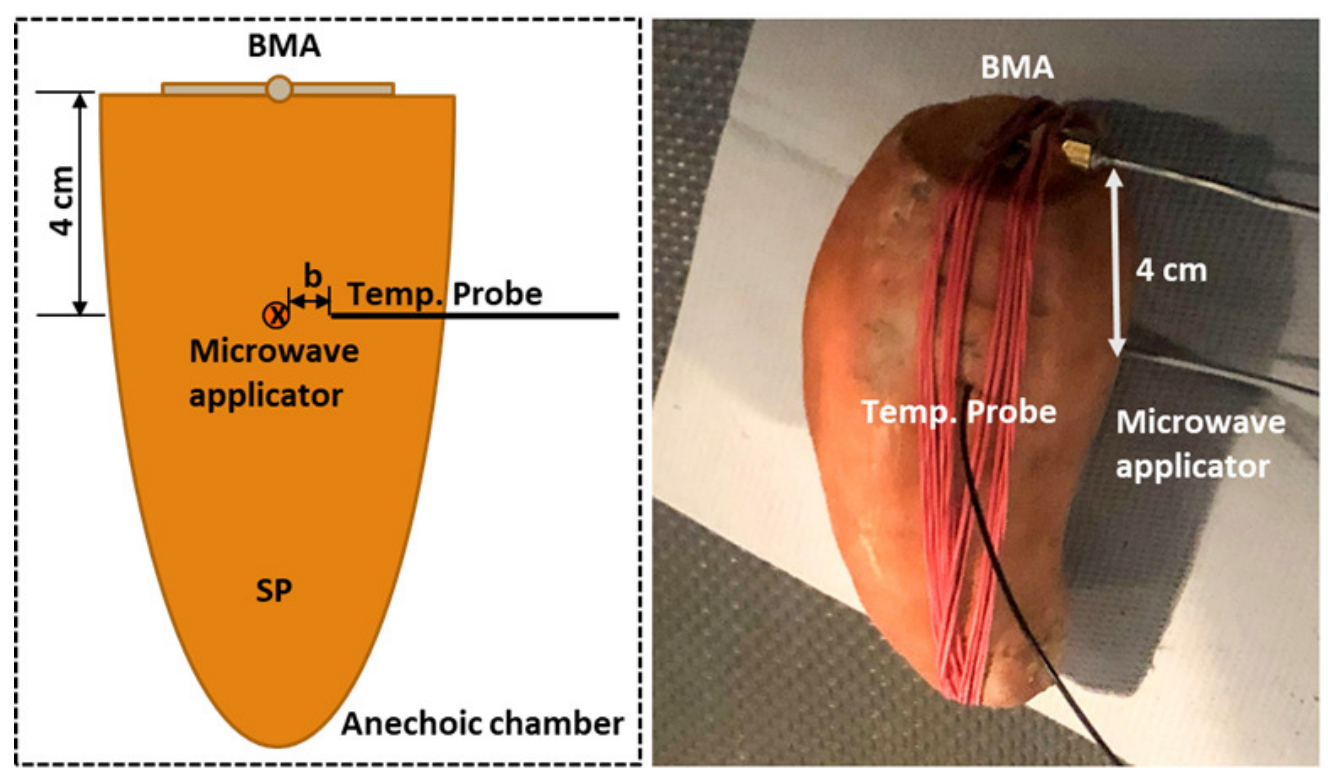

Figure 6. MWA experimental setup for SP.

\section{Results}

The S-parameters of both microwave applicators in SP and the BMA on SP are measured from 2.4 to $2.5 \mathrm{GHz}$ and compared at $2.45 \mathrm{GHz}$, as shown in Figure A2. The $S_{11}$ (reflection loss of the self-developed applicator) is $-29.2 \mathrm{~dB}$, compared to $-14.1 \mathrm{~dB}$ for the commercial applicator. Then, $S_{22}$ (reflection loss of the BMA) is $-19.7 \mathrm{~dB}$ which is below the $-10 \mathrm{~dB}$ threshold. Furthermore, $S_{21}$ (power received at the BMA) is $-39.1 \mathrm{~dB}$ for the self-developed applicator as compared to $-43.2 \mathrm{~dB}$ for the commercial applicator.

The reflected power of the 10 min MWA experiment with the two applicators at $80 \mathrm{~W}$ for $2.45 \mathrm{GHz}$ is shown in Figure A3. The self-developed and the commercial applicator show a constant reflected power of $4.905 \mathrm{~W}$ and $1.115 \mathrm{~W}$, respectively, for about $5 \mathrm{~min}$. It can be observed that the curve of the reflected power of both applicators develops similarly, and the reflected power of the self-developed applicator is higher than that of 
the commercial applicator. The change in reflected power with time can be attributed to the applicator miss-matching due to the progressive ablation process. As can be seen in the photo of the cut open SP in Figure A5, a burn hole forms immediately around the applicator at high power $(80 \mathrm{~W})$. After the validation and benchmarking of the test equipment, the self-developed applicator and the BMA: received and reflected power during MWA, ablation zone SAD as a function of time and received power as a function of temperature are presented.

The received and reflected powers at $2.45 \mathrm{GHz}$ during MWA at $50 \mathrm{~W}$ for $600 \mathrm{~s}$ in SP are shown in Figure 7. The experiment was performed a number of times on different days with the good and poor coupling of microwave power as shown in Figure A3; however, the results presented here, are with the most stable and consistent experimental environment on a same day. In a first measurement (blue curve), the received power drops from $30.9 \mathrm{~mW}$ to $29 \mathrm{~mW}$ in the first minute. It then rises to $32.4 \mathrm{~mW}$ after another $30 \mathrm{~s}$. Afterward, this shows a steady drop from $32.4 \mathrm{~mW}$ to $21.3 \mathrm{~mW}$ in last $510 \mathrm{~s}$ of the measurement. The reflected power in first measurement increases from $0.1 \mathrm{~W}$ to $0.4 \mathrm{~W}$ in the first minute. At $90 \mathrm{~s}$, no reflected power is measured. After that, the reflected power gradually increases to a maximum value of $2.1 \mathrm{~W}$. Similarly, in the second measurement (red curve), the received power starts at $16.3 \mathrm{~mW}$ and drops to $12.8 \mathrm{~mW}$ in the first $60 \mathrm{~s}$. After another $30 \mathrm{~s}$, it increases to $16.4 \mathrm{~mW}$ and then drops steadily to $9.8 \mathrm{~mW}$ after $600 \mathrm{~s}$. The reflected power of the second measurement also increases from $0.1 \mathrm{~W}$ to $0.7 \mathrm{~W}$ in the first $60 \mathrm{~s}$. No reflected power is measured for $90 \mathrm{~s}$ again and afterwards, the reflected power linearly increases from $0 \mathrm{~W}$ to $2.1 \mathrm{~W}$ until the end of measurement at $600 \mathrm{~s}$.

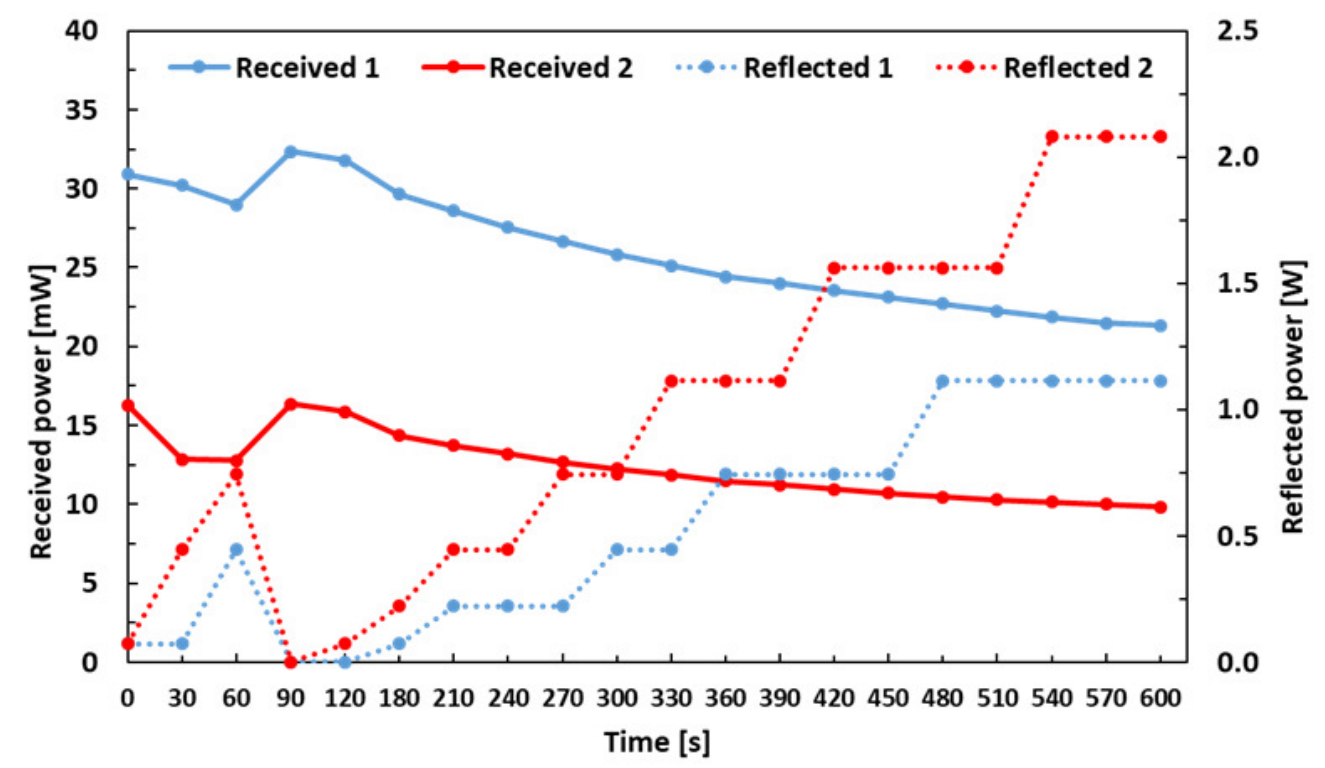

Figure 7. Received and reflected power vs. time for $50 \mathrm{~W}$ MWA in SP.

The $S_{11}$ (reflection loss) as a function of time for $50 \mathrm{~W}$ and $40 \mathrm{~W}$ in SP, and $25 \mathrm{~W}$ and $40 \mathrm{~W}$ in bovine liver, is shown in Figure 8 . For the $50 \mathrm{~W}$ experiment, the $S_{11}$ of the SP increases from $-28.3 \mathrm{~dB}$ to $-19.2 \mathrm{~dB}$ in the first minute. Afterwards, it drops to $-39.8 \mathrm{~dB}$ at $90 \mathrm{~s}$ and then gradually increases to $-15 \mathrm{~dB}$ at $600 \mathrm{~s}$, which is comparable to $25 \mathrm{~W}$ MWA experiment in bovine liver for $600 \mathrm{~s}$, as reported in [32]. The measurement values represented by green curve are taken from Figure 7 in [32]. Similarly, for the $40 \mathrm{~W}$ experiment, the $S_{11}$ of the SP increases from $-17.3 \mathrm{~dB}$ to $-14.1 \mathrm{~dB}$ in $180 \mathrm{~s}$, which is comparable to the $40 \mathrm{~W}$ MWA experiment in bovine liver for $210 \mathrm{~s}$, as reported in [32]. The measurement values represented by black curve are also taken from Figure 7 in [32]. 


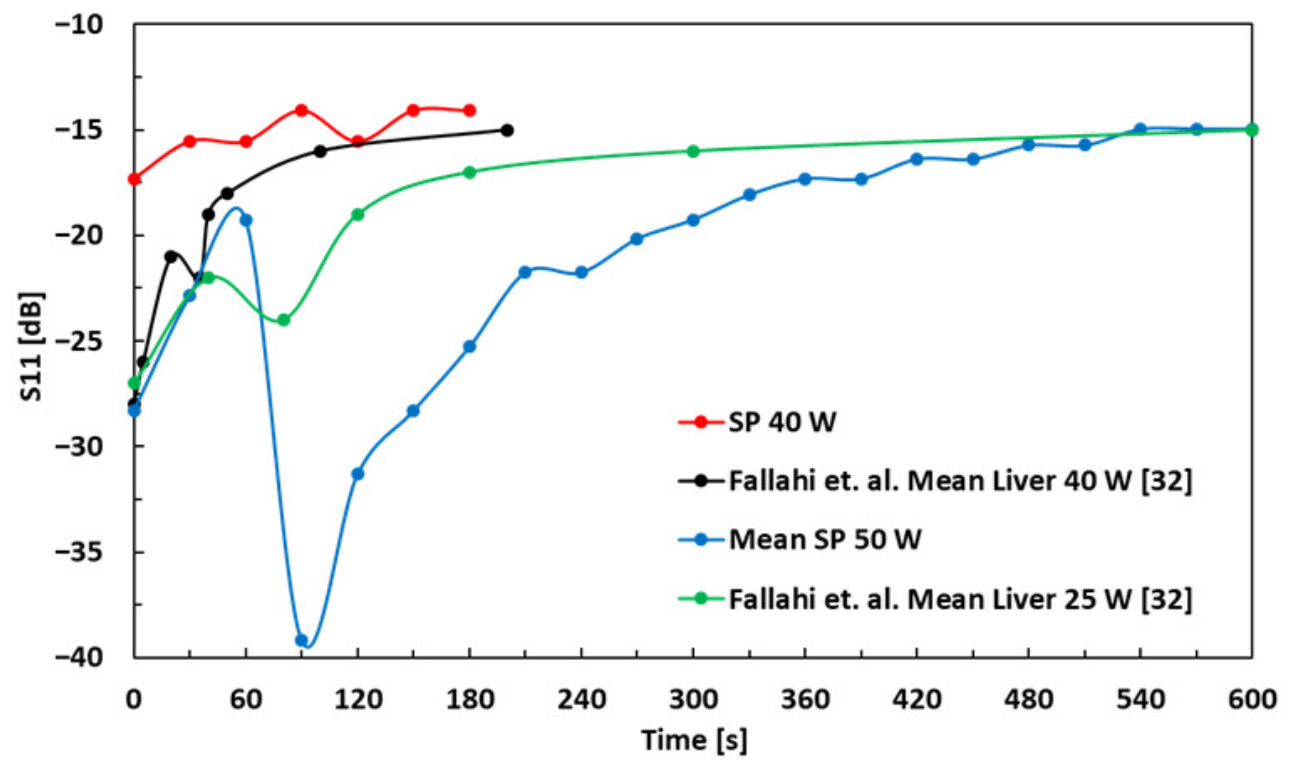

Figure 8. $S_{11}$ as a function of time for $25 \mathrm{~W}$ [32], $40 \mathrm{~W}$ [32] and $50 \mathrm{~W}$ MWA experiments.

The ablation zone SAD in SP as a function of time for 50 and $80 \mathrm{~W}$ powers at $2.45 \mathrm{GHz}$ is shown in Figure 9 and is also compared with MWA experiment in bovine liver, published in [33]. The ablation zone is elliptical with a short axis perpendicular to the microwave applicator. The measurement values denoted by green dots are taken from Figure 10 in [33], where an MWA experiment in bovine liver using $30 \mathrm{~W}$ power was conducted and analyzed, similarly to the method described here. The SP is cut open at the applicator puncture site after each experiment and MWA SAD perpendicular to the applicator channel is noted with an error of $\pm 0.1 \mathrm{~cm}$. The SAD of the ablation zone at $50 \mathrm{~W}$ is from 0.6 to $3.3 \mathrm{~cm}$ and for $80 \mathrm{~W}, 1.5$ to $4.5 \mathrm{~cm}$.

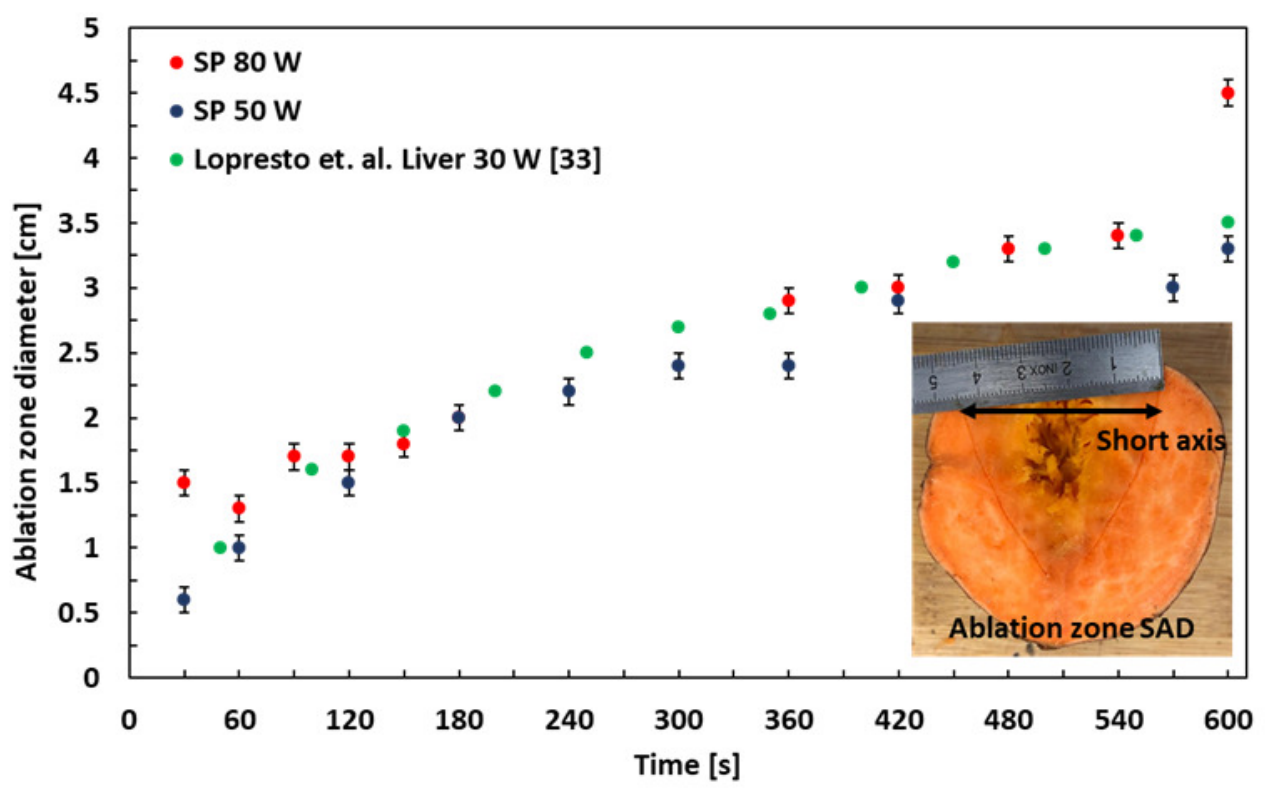

Figure 9. Ablation zone SAD as a function of time for $50 \mathrm{~W}$ and $80 \mathrm{~W}$ in SP and liver [33].

Figure 10 shows the SP MWA temperature as a function of time at $2.45 \mathrm{GHz}$ for 50 and $80 \mathrm{~W}$ powers. The temperature measurements of SP are compared with those in MWA experiments in bovine liver at $60 \mathrm{~W}$ for $130 \mathrm{~s}$, as reported in [14] and porcine liver at $75 \mathrm{~W}$ power for $300 \mathrm{~s}$, as reported in [34]. The measurement values in the brown curve are 
taken from Figure 6 in [14], corresponding to curve 'FBG 2.2' for $5 \mathrm{~mm}$, and similarly, the measurement values in the green curve are taken from Figure 10c in [34], corresponding to curve ' $\mathrm{A}$ ' for $4 \mathrm{~mm}$. The tip of the temperature sensor is $3-4 \mathrm{~mm}$ from the microwave applicator slot in both $50 \mathrm{~W}$ and $80 \mathrm{~W}$ MWA experiments in SP, as shown in the figure inset. The starting temperature of $50 \mathrm{~W}$ SP MWA as in the blue curve, increases from $16.2^{\circ} \mathrm{C}$ to $85.4{ }^{\circ} \mathrm{C}$ after $180 \mathrm{~s}$ and remains constant until the end of the measurement. This is compared to [14] as in the brown curve, the values are comparable at $90{ }^{\circ} \mathrm{C}$ after which the temperature values of $60 \mathrm{~W}$ MWA of liver keeps on increasing until $114{ }^{\circ} \mathrm{C}$ at $130 \mathrm{~s}$. Similarly, the starting temperature of $80 \mathrm{~W}$ SP MWA as in the red curve, increases from $18.9^{\circ} \mathrm{C}$ to $98.7^{\circ} \mathrm{C}$ after $180 \mathrm{~s}$ and remains constant until the end of the measurement. This is compared to [34] as in the green curve, the values are comparable at $60^{\circ} \mathrm{C}$ after which the temperature values of $75 \mathrm{~W}$ MWA of liver keep on increasing until $136^{\circ} \mathrm{C}$ at $300 \mathrm{~s}$.

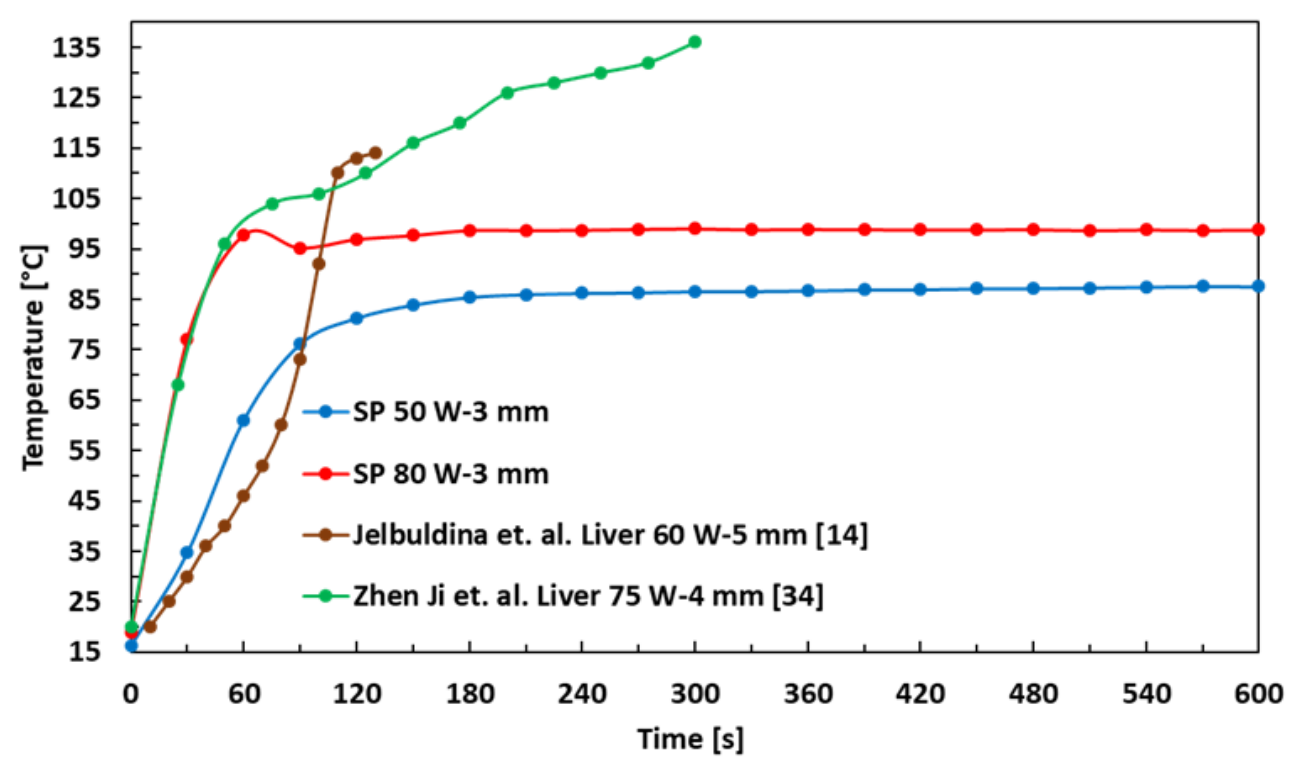

Figure 10. Temperature vs. time in MWA experiments [14,34].

The relative received power is shown as a function of temperature inside SP for $50 \mathrm{~W}$ MWA in Figure 11. Three measurements are taken with the position of the temperature probe at $2 \mathrm{~mm}, 3.3 \mathrm{~mm}$ and $10 \mathrm{~mm}$ away from the center of the ablation zone. In all three measurements, it is observed that after a certain temperature, the relative received power starts decreasing with the increase in temperature. In the measurement with the temperature probe at $3.3 \mathrm{~mm}$ away from the center of the ablation zone (blue dots), the relative received power drops from 1 at $76{ }^{\circ} \mathrm{C}$ to 0.6 at $88^{\circ} \mathrm{C}$, representing a $40 \%$ relative change. Therefore, a correlation can be drawn between a rise in temperature and a decrease in received power which could be attributed to more variation in material properties with rising temperature and thus increased losses in SP due to heating. Finally, some pictures of the SP MWA results for different power and time settings are shown in Figure A5. A summary of all quantitative results with minimum and maximum values for different time and temperature settings, for $50 \mathrm{~W}$ and $80 \mathrm{~W}$ MWA experiments in SP, is shown in Table 3.

Table 3. Summary of all quantitative results for $50 \mathrm{~W}$ and $80 \mathrm{~W}$ MWA experiments with SP.

\begin{tabular}{|c|c|c|c|c|}
\hline Result & $50 \mathrm{~W}$ (min.) & $50 \mathrm{~W}$ (max.) & $80 \mathrm{~W}$ (min.) & $80 \mathrm{~W}$ (max.) \\
\hline Reflected power & $0 \mathrm{~W}$ & $2.1 \mathrm{~W}$ & $0 \mathrm{~W}$ & $4.9 \mathrm{~W}$ \\
\hline Received power & $9.8 \mathrm{~mW}$ & $32.4 \mathrm{~mW}$ & $21.6 \mathrm{~mW}$ (Figure A4) & $30.6 \mathrm{~mW}$ (Figure A4) \\
\hline Ablation zone SAD & $0.6 \mathrm{~cm}(30 \mathrm{~s})$ & $3.3 \mathrm{~cm}(600 \mathrm{~s})$ & $1.5 \mathrm{~cm}(30 \mathrm{~s})$ & $4.5 \mathrm{~cm}(600 \mathrm{~s})$ \\
\hline Temperature vs. time & $16^{\circ} \mathrm{C}(0 \mathrm{~s})$ & $88^{\circ} \mathrm{C}(600 \mathrm{~s})$ & $19^{\circ} \mathrm{C}(0 \mathrm{~s})$ & $99^{\circ} \mathrm{C}(600 \mathrm{~s})$ \\
\hline Received power vs. temperature & $9.82 \mathrm{~mW}\left(88^{\circ} \mathrm{C}\right)$ & $32.25 \mathrm{~mW}\left(53.5^{\circ} \mathrm{C}\right)$ & - & - \\
\hline
\end{tabular}




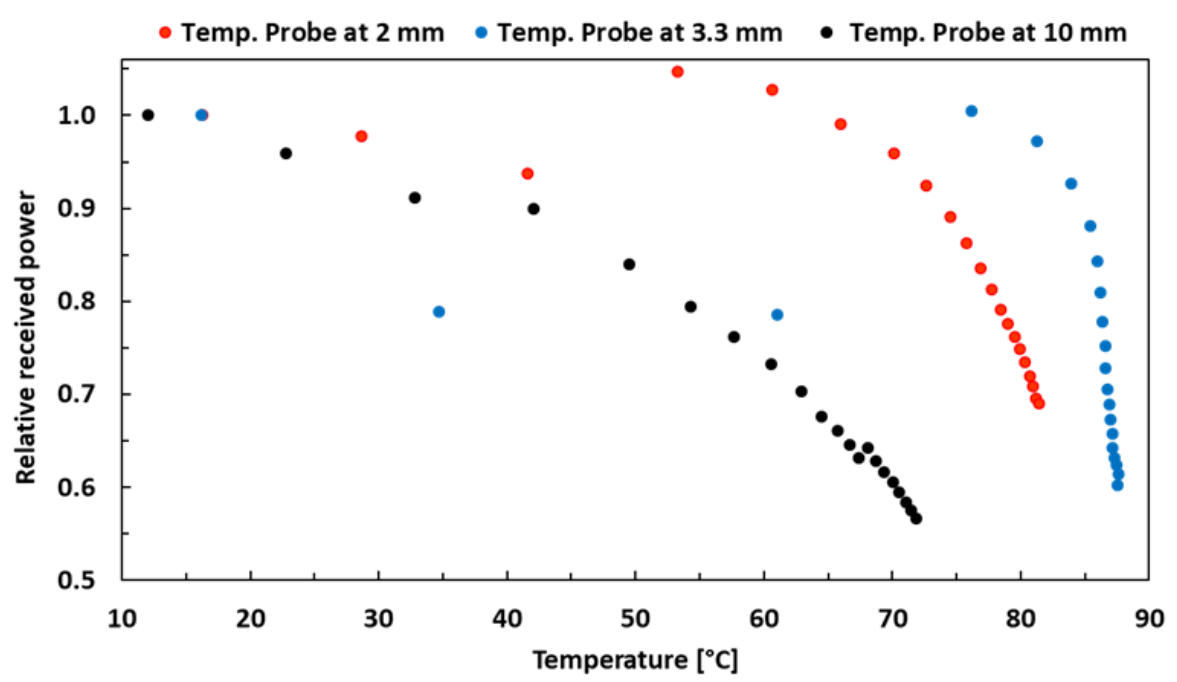

Figure 11. Received power vs. temperature for 50 W MWA in SP.

\section{Discussion}

Two microwave powers, $50 \mathrm{~W}$ and $80 \mathrm{~W}$, are used for MWA in SP. In MWA with $80 \mathrm{~W}$, some burning of the tissue can be observed, as shown in the MWA example of a fresh SP at $80 \mathrm{~W} / 10 \mathrm{~min}$ in Figure A5. Therefore, powers above $80 \mathrm{~W}$ are not used due to burning effects and also because of the maximum power rating of the self-developed applicator $(93 \mathrm{~W})$. However, a comparison is made between $50 \mathrm{~W}$ and $80 \mathrm{~W}$ MWA experiments in terms of maximum and minimum received powers, reflected powers, ablation zone SADs, time-dependent temperatures and temperature-depended received powers, as illustrated in Table 3. As expected, the maximum reflected power and minimum received power, ablation zone SAD and temperature is more for $80 \mathrm{~W}$ MWA than $50 \mathrm{~W}$.

The results were also compared with the state of the art in the MWA of animal liver. The comparison of dielectric constant, electrical conductivity, reflected power, ablation zone SAD temperature as a function of time between SP and animal liver is shown in Table 4. A close agreement of values support SP as an alternative tissue material for MWA experiments in liver. As shown in Table 4 and Figure A1, the $\epsilon_{r}$ and $\sigma$ of SP and liver are comparable in the $50-60{ }^{\circ} \mathrm{C}$ temperature range. However, as the temperature increases, the liver loses water rapidly and thus $\epsilon_{r}$ and $\sigma$ also decrease sharply but since the water in SP accumulates with increasing temperature, $\epsilon_{r}$ and $\sigma$ increase above the room temperature value.

Table 4. Comparison between SP and animal liver MWA.

\begin{tabular}{ccc}
\hline Result & SP & Liver \\
\hline$\epsilon_{r}$ & $50.3\left(63^{\circ} \mathrm{C}\right)$ & $40\left(60{ }^{\circ} \mathrm{C}\right)[32]$ \\
$\sigma(\mathrm{S} / \mathrm{m})$ & $1.97\left(51^{\circ} \mathrm{C}\right)$ & $1.75\left(50{ }^{\circ} \mathrm{C}\right)[32]$ \\
Reflection loss & $15 \mathrm{~dB}(50 \mathrm{~W}-600 \mathrm{~s})$ & $15 \mathrm{~dB}(25 \mathrm{~W}-600 \mathrm{~s})[32]$ \\
Reflection loss & $14 \mathrm{~dB}(40 \mathrm{~W}-180 \mathrm{~s})$ & $15 \mathrm{~dB}(40 \mathrm{~W}-210 \mathrm{~s})[32]$ \\
Temperature & $76.1^{\circ} \mathrm{C}(50 \mathrm{~W}-90 \mathrm{~s}-3 \mathrm{~mm})$ & $73.0^{\circ} \mathrm{C}(50 \mathrm{~W}-90 \mathrm{~s}-5 \mathrm{~mm})[14]$ \\
Temperature & $97.8^{\circ} \mathrm{C}(80 \mathrm{~W}-60 \mathrm{~s}-3 \mathrm{~mm})$ & $100^{\circ} \mathrm{C}(75 \mathrm{~W}-60 \mathrm{~s}-4 \mathrm{~mm})[34]$ \\
Ablation zone SAD & $3.3 \mathrm{~cm}(50 \mathrm{~W}-600 \mathrm{~s})$ & $3.5 \mathrm{~cm}(30 \mathrm{~W}-600 \mathrm{~s})[33]$ \\
\hline
\end{tabular}

The measure of reflection loss of the microwave applicators in liver and SP not only demonstrates an efficient design of the applicator, but also depicts the matching of the applicator to the material itself. Therefore, an almost equal reflection loss for SP and liver is due to the same material characteristics as observed in Table 1. Secondly, as observed in Figure 10 and Table 4, the temperature in SP and animal liver is equal until a point after which the temperature remains constant in SP but keeps on increasing in the MWA in 
animal liver. A possible explanation for this observation is that in MWA in animal liver, the water loss is rapid due to MWA and also from the open surface of the liver. On the contrary, in case of SP, the skin and outer tissues of the SP stop the water from escaping and the water evaporated by MWA is replaced by the water seeping in from the surrounding tissues of the ablation zone of SP. This phenomena in SP is closer to an MWA of liver in which the loss of water from the liver is not so rapid as compared to the MWA of liver. Lastly, a similar explanation is given for the power difference in the ablation zone SAD comparison in Table 4 . It is seen that the ablation zone SAD is slightly bigger with $30 \mathrm{~W}$ MWA in the liver than $50 \mathrm{~W}$ MWA in SP, which is due to the rapid loss of water in MWA in liver.

This is the first study to directly receive a signal from microwave applicator during a MWA process with the help of a surface BMA. The main target application of this work is the development of an imaging system for temperature monitoring and microwave applicator guidance for MWA. The contrast in tissue dielectric and electrical conductive properties between hot and cold tissue, enable a power change at the surface BMA. The results show that it is possible to recreate MWA process within an SP for simulation studies before trying for actual clinical studies. With the help of the presented test setup, in situ monitoring of the MWA process via surface BMAs can also be done by using the correlation between ablation zone temperature and received power, thereby employing a data processing algorithm for calculating ablation zone dimensions. The test setup can also be used for testing new microwave applicator designs for better matching to the target tissue. A separate work could be carried out for the comparison of temperature development and thermal damage information in SPs with simulation studies. However, the limitation of MWA in SP is that there is no blood perfusion (heat sink) effect in SPs as there is in the MWA of liver and there are no data available for change in the material properties of SP due to tissue burning (above $80^{\circ} \mathrm{C}$ ).

In conclusion, with help of this work, a correlation could be drawn between the rise in temperature during SP MWA and received power at the surface BMA. The work can be extended to multiple array antennas for the $2 \mathrm{D}$ and $3 \mathrm{D}$ estimation of the ablation zone. The experimental setup prepared for the purpose of this publication can be used for testing new applicator designs and also in testing other materials for MWA experiments.

Author Contributions: Conceptualization, M.S.K., G.R., B.S. and A.B.; methodology, M.S.K., G.R., B.S. and A.B.; software, M.S.K., M.H. and S.M.T.; validation, M.S.K., M.H. and S.M.T.; formal analysis, M.S.K., B.S. and A.B.; investigation, M.S.K., M.H. and S.M.T.; resources, A.B.; data curation, M.S.K., M.H., S.M.T., B.S. and A.B.; writing—original draft preparation, M.S.K., M.H. and S.M.T.; writingreview and editing, M.S.K., M.H., S.M.T., G.R., B.S. and A.B.; visualization, M.S.K., M.H. and S.M.T.; supervision, G.R., B.S. and A.B.; project administration, G.R., B.S. and A.B.; funding acquisition, A.B. All authors have read and agreed to the published version of the manuscript.

Funding: This research received no external funding.

Acknowledgments: Authors would like to thank and acknowledge the support of med. Thomas J. Vogl and Frank Huebner at Institute of Diagnostic and Interventional Radiology in University Hospital, Frankfurt for arranging a visit to the hospital for observing a real microwave ablation procedure, providing the commercial microwave applicator being used at the hospital and fruitful technical discussion during the course of project.

Conflicts of Interest: The authors declare no conflict of interest. The funders had no role in the design of the study; in the collection, analyses, or interpretation of data; in the writing of the manuscript, or in the decision to publish the results. 


$\begin{array}{ll}\text { Abbreviations } \\ \text { The following abbreviations are used in } \\ \text { MWA } & \text { Microwave Ablation } \\ \text { MRI } & \text { Magnetic Resonance Imaging } \\ \text { UWB } & \text { Ultra Wide-Band } \\ \text { BMA } & \text { Body Matched Antenna } \\ \text { SAD } & \text { Short Axis Diameter } \\ \text { SMA } & \text { Sub-Miniature Version-A } \\ \text { GUI } & \text { Graphical User Interface } \\ \text { VNA } & \text { Vector Network Analyzer } \\ \text { RF } & \text { Radio Frequency } \\ \text { SP } & \text { Sweet Potato }\end{array}$

Appendix A

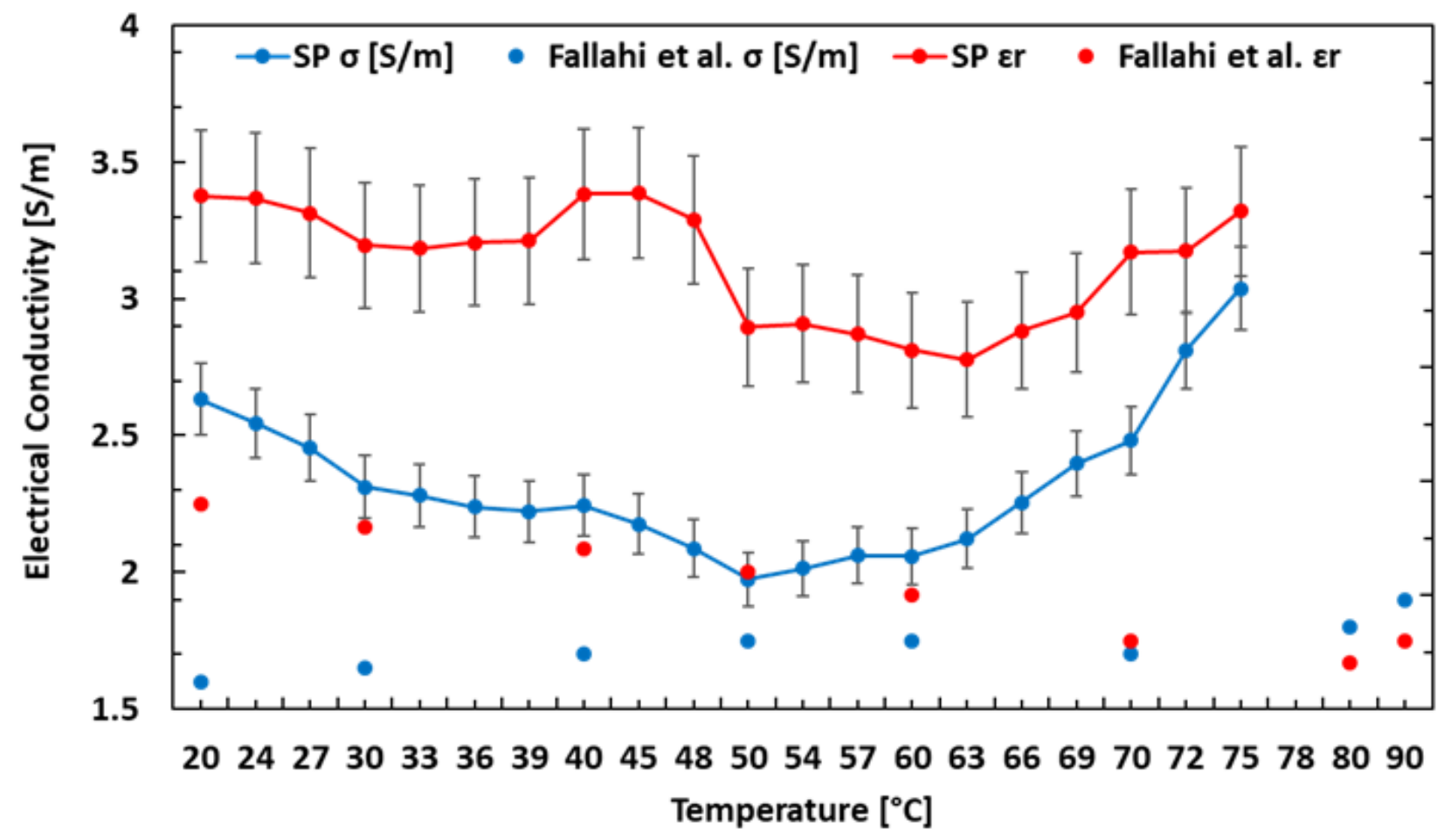

Figure A1. Change in electrical conductivity and dielectric constant of SP and liver with temperature at $2.45 \mathrm{GHz}$. 


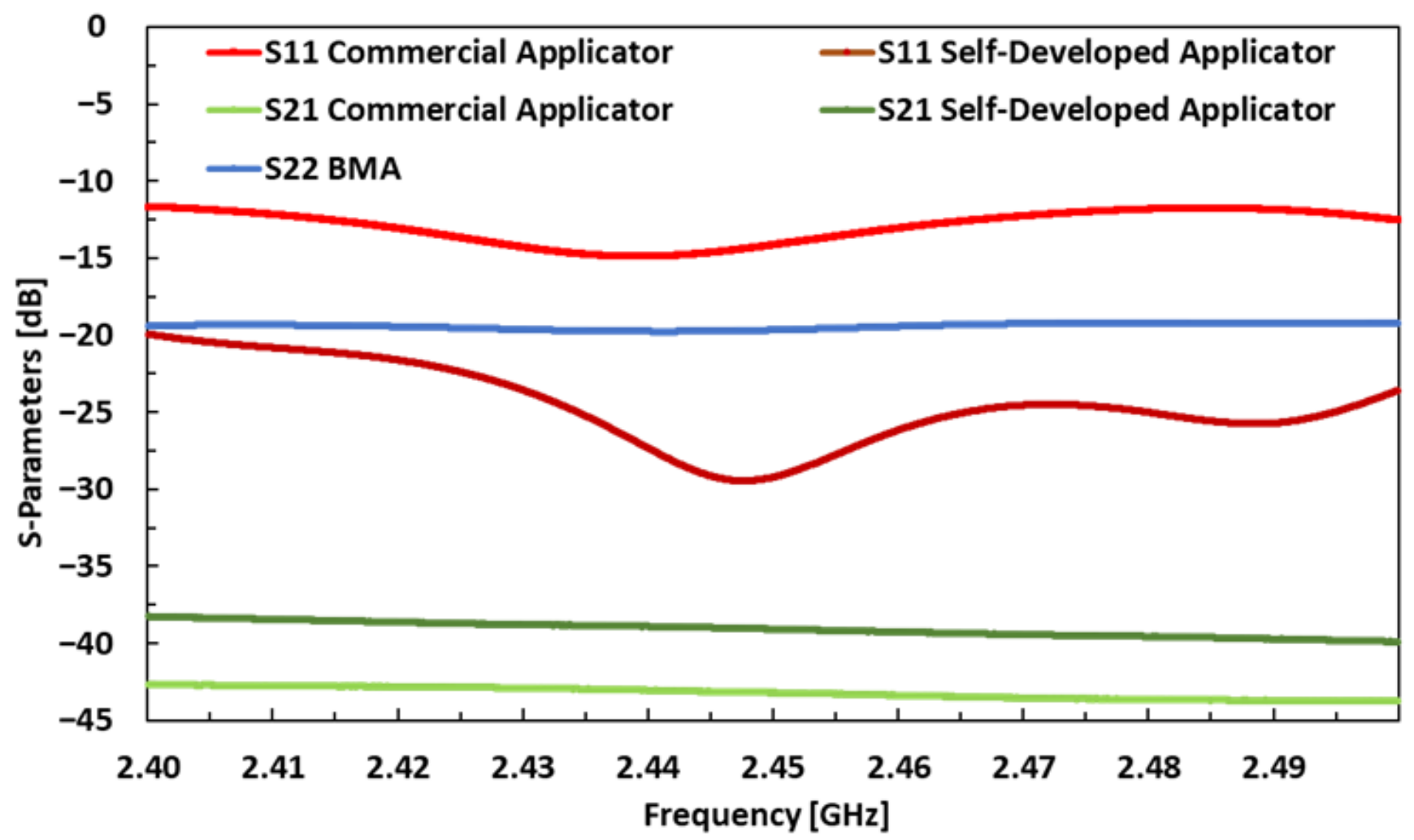

Figure A2. S-parameters measurement of self-developed microwave applicator, commercial applicator and BMA in SP.

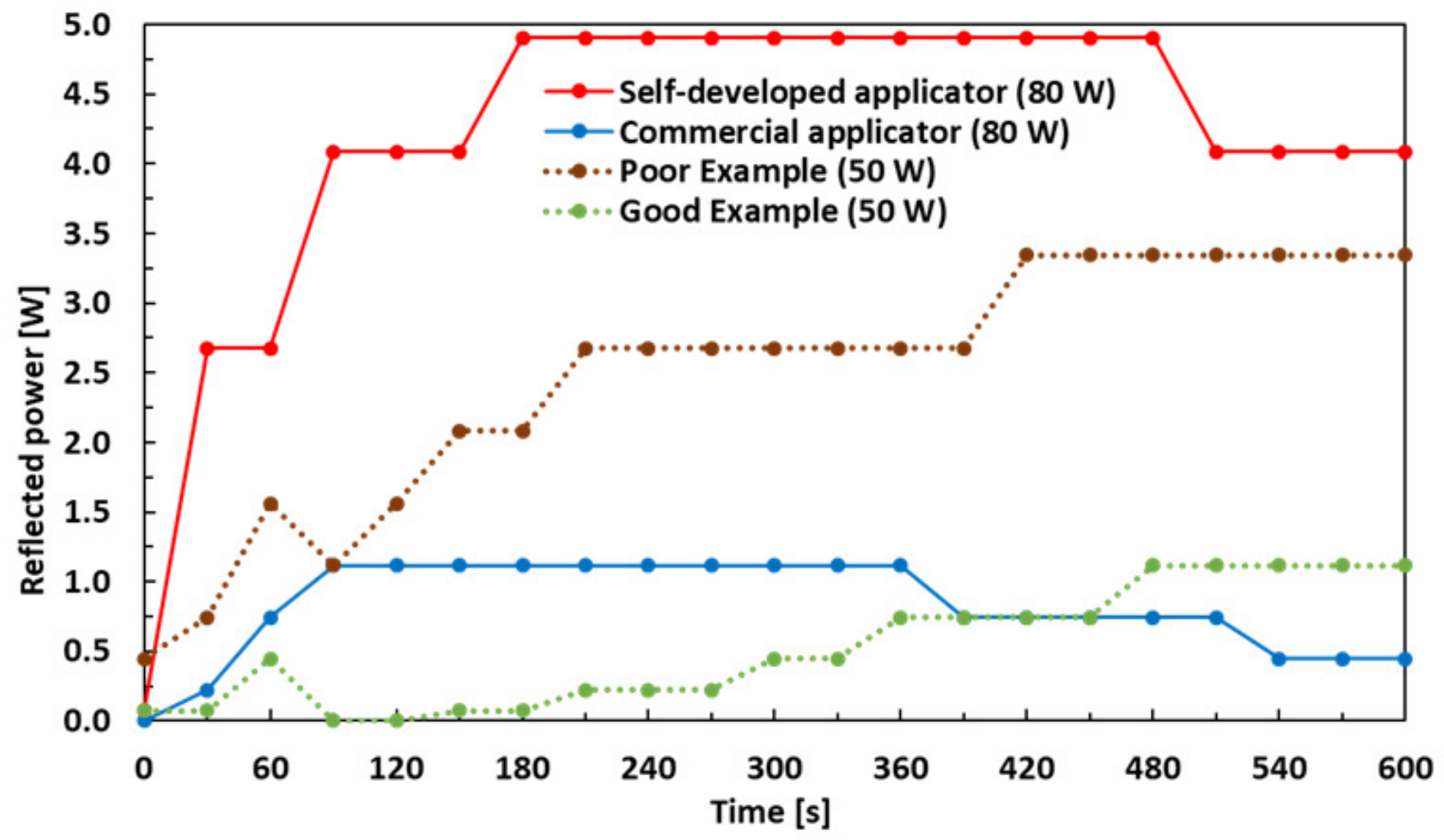

Figure A3. Comparison of reflected powers of commercial and self-developed applicators for 80 W MWA and poor and good examples of self-developed applicator matching for 50 W MWA in SP. 


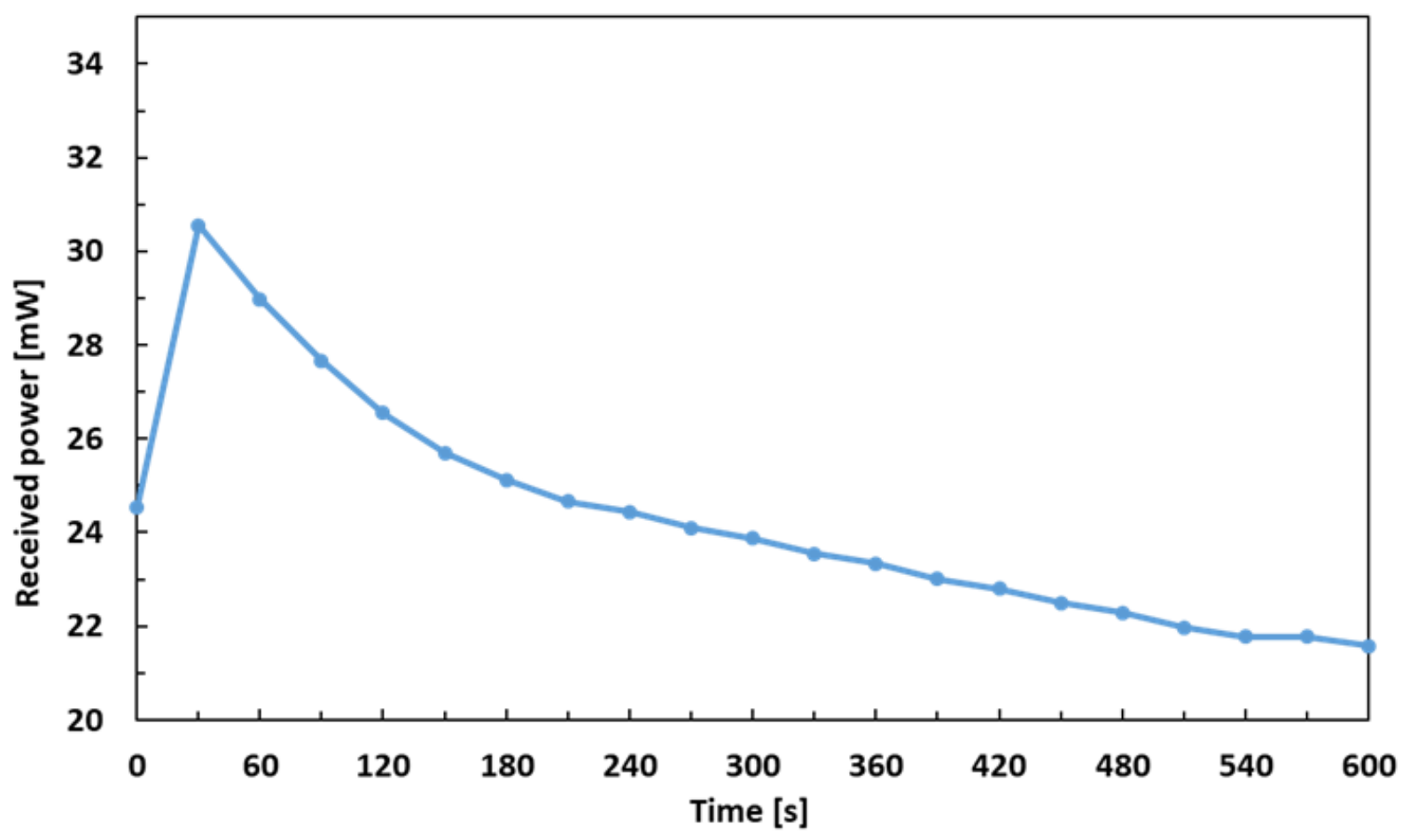

Figure A4. Received power vs. time for 80 W MWA in SP.

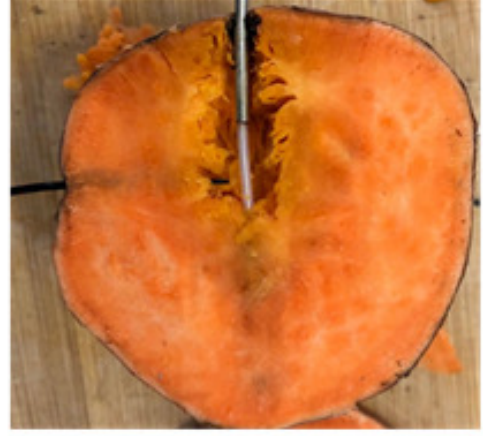

Fresh SP $80 \mathrm{~W} / 10 \mathrm{~min}$

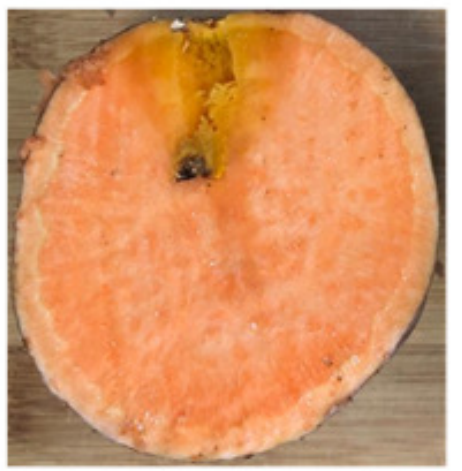

Two weeks old SP 50 W / 10 min

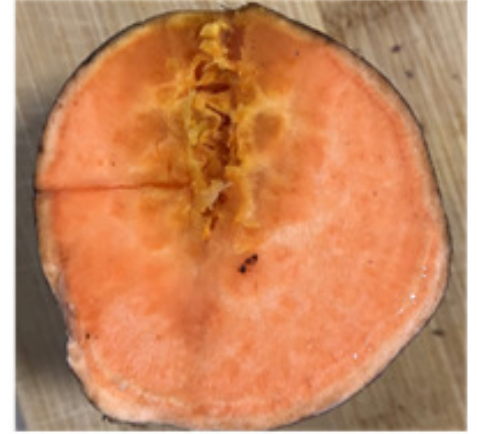

Fresh SP $50 \mathrm{~W} / 10 \mathrm{~min}$

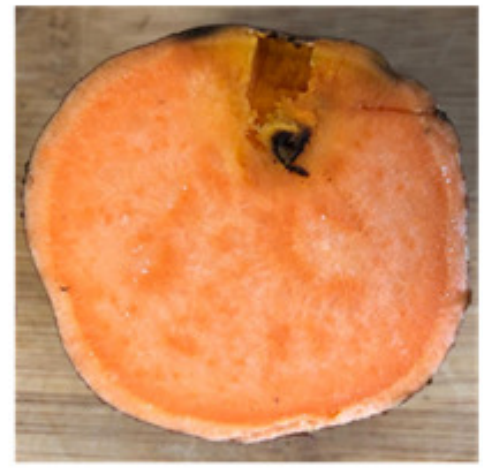

Two weeks old SP 50 W / 10 min

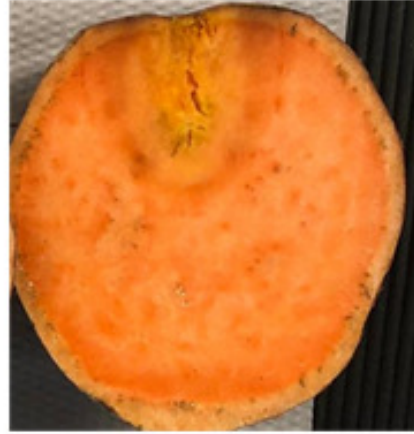

Fresh SP $50 \mathrm{~W} / 6 \mathrm{~min}$

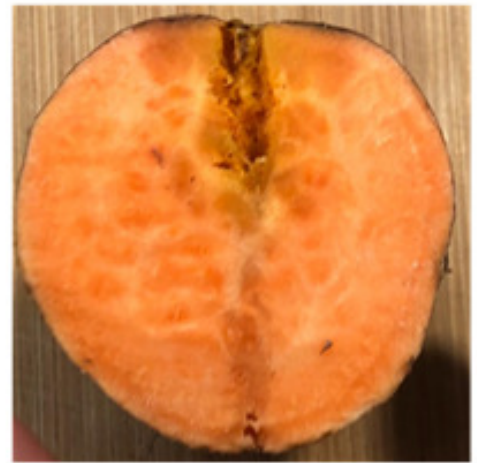

Fresh SP 50 W / 5 min

Figure A5. MWA result examples of SP. 


\section{References}

1. Bray, F.; Ferlay, J.; Soerjomataram, I.; Siegel, R.L.; Torre, L.A.; Jemal, A. Global cancer statistics 2018: GLOBOCAN estimates of incidence and mortality worldwide for 36 cancers in 185 countries. CA Cancer J. Clin. 2018, 68, 394-424. [CrossRef] [PubMed]

2. National-Cancer-Institute. Cancer Stat Facts: Liver and Intrahepatic Bile Duct Cancer; National Cancer Institute: Bethesda, MD, USA, 2021.

3. Short, J.; Turner, P. Physical hyperthermia and cancer therapy. Proc. IEEE 1980, 68, 133-142. [CrossRef]

4. Taylor, L. Implantable radiators for cancer therapy by microwave hyperthermia. Proc. IEEE 1980, 68, 142-149. [CrossRef]

5. González-Suárez, A.; Berjano, E. Comparative Analysis of Different Methods of Modeling the Thermal Effect of Circulating Blood Flow During RF Cardiac Ablation. IEEE Trans. Biomed. Eng. 2016, 63, 250-259. [CrossRef]

6. Chung, S.; Vafai, K. Mechanobiology of low-density lipoprotein transport within an arterial wall-Impact of hyperthermia and coupling effects. J. Biomech. 2014, 47, 137-147. [CrossRef] [PubMed]

7. You, J.; Guo, P.; Auguste, D. A drug-delivery vehicle combining the targeting and thermal ablation of HER2+ breast-cancer cells with triggered drug release. Angew. Chem. Int. Ed. Engl. 2013, 52, 4141-4146. [CrossRef] [PubMed]

8. Andreozzi, A.; Iasiello, M.; Netti, P.A. A thermoporoelastic model for fluid transport in tumour tissues. J. R. Soc. Interface 2019, 16. [CrossRef]

9. Andreozzi, A.; Iasiello, M.; Netti, P.A. Effects of pulsating heat source on interstitial fluid transport in tumour tissues. J. R. Soc. Interface 2020, 17. [CrossRef]

10. Vogl, T.J.; Helmberger, T.; Mack, M.G.; Reiser, M.F. (Eds.) Percutaneous Tumor Ablation in Medical Radiolog, 1st ed.; Springer: Berlin/Heidelberg, Germany, 2008; [CrossRef]

11. Sonnenberg, E.V.; McMullen, W.; Solbiati, L. (Eds.) Tumor Ablation Principles and Practice, 1st ed.; Springer: New York, NY, USA, 2005; [CrossRef]

12. Brace, C. Thermal Tumor Ablation in Clinical Use. IEEE Pulse 2011, 2, 28-38. [CrossRef]

13. Schena, E.; Saccomandi, P.; Tosi, D.; Davrieux, F.; Gassino, R.; Massaroni, C.; Presti, D.L.; Costamagna, G.; Perrone, G.; Vallan, A.; et al. Solutions to Improve the Outcomes of Thermal Treatments in Oncology: Multipoint Temperature Monitoring. IEEE J. Electromagn. RF Microw. Med. Biol. 2018, 2, 172-178. [CrossRef]

14. Jelbuldina, M.; Korobeinyk, A.; Korganbayev, S.; Tosi, D.; Dukenbayev, K.; Inglezakis, V.J. Real-Time Temperature Monitoring in Liver During Magnetite Nanoparticle-Enhanced Microwave Ablation With Fiber Bragg Grating Sensors: Ex Vivo Analysis. IEEE Sens. J. 2018, 18, 8005-8011. [CrossRef]

15. Reimann, C.; Schülsler, M.; Schmidt, S.; Hübner, F.; Bazrafshan, B.; Vogl, T.; Jakoby, R. Microwave Ablation Applicator with Sensing Capabilities for Thermal Treatment of Malignant Tissue. In Proceedings of the 2018 IEEE/MTT-S International Microwave Symposium-IMS, Philadelphia, PA, USA, 10-15 June 2018; pp. 1278-1281. [CrossRef]

16. Hue, Y.K.; Guimaraes, A.R.; Cohen, O.; Nevo, E.; Roth, A.; Ackerman, J.L. Magnetic Resonance Mediated Radiofrequency Ablation. IEEE Trans. Med. Imaging 2018, 37, 417-427. [CrossRef]

17. Kägebein, U.M.; Speck, O.P.; Wacker, F.M.; Hensen, B.M. Motion Correction in Proton Resonance Frequency-based Thermometry in the Liver. Top. Magn. Reson. Imaging 2018, 27, 53-61. [CrossRef]

18. Wang, M.; Crocco, L.; Cavagnaro, M. On the Design of a Microwave Imaging System to Monitor Thermal Ablation of Liver Tumors. IEEE J. Electromagn. RF Microw. Med. Biol. 2021, 1. [CrossRef]

19. Scapaticci, R.; Lopresto, V.; Pinto, R.; Cavagnaro, M.; Crocco, L. Monitoring Thermal Ablation via Microwave Tomography: An Ex Vivo Experimental Assessment. Diagnostics 2018, 8, 81. [CrossRef]

20. Khan, M.S.; Rose, G.; Schweizer, B.; Brensing, A. EM-Thermal Co-Simulation of Microwave Ablation Applicator in Liver Tissue Phantom with Bowtie-Slot Surface Antenna. In Proceedings of the 2020 14th European Conference on Antennas and Propagation (EuCAP), Copenhagen, Denmark, 15-20 March 2020.

21. Nelson, S.; Forbus, W., Jr.; Lawrence, K. Permittivities of fresh fruits and vegetables at 0.2 to 20 GHz. J. Microw. Power Electromagn. Energy 1994, 81-93. [CrossRef]

22. Niehues, S.; Unger, J.; Malinowski, M. Liver volume measurement: Reason of the difference between CT-volumetry and intraoperative determination and how to cope it. Eur. J. Med Res. 2010. [CrossRef]

23. Kakimov, A.; Suychinov, A.; Tsoy, A.; Mustambayev, N.; Ibragimov, N.; Kuderinova, N.; Mirasheva, G.; Yessimbekov, Z Nutritive and Biological Value of Liver and Blood of Various Slaughtered Animals. J. Pharm. Res. Int. 2018, 1-5. [CrossRef]

24. Gabriel, C. Compilation of the Dielectric Properties of Body Tissues at RF and Microwave Frequencies; King's College London: London, UK, 1996.

25. Medtronic Covidien. Emprint ${ }^{\mathrm{TM}}$ SX Navigation Antennas and Accessories; Medtronic Covidien : Minneapolis, MN, USA, 2021.

26. Alonzo, M.; Bos, A.; Bennett, S.; Ferral, H. The Emprint ${ }^{\mathrm{TM}}$ Ablation System with Thermosphere ${ }^{\mathrm{TM}}$ Technology: One of the Newer Next-Generation Microwave Ablation Technologies. Semin. Interv. Radiol. 2015. [CrossRef]

27. Kuhne Electronic GmbH. Microwave Generator KU SG 2.45-250A, v1.0.1 ed.; Kuhne Electronic GmbH: Berg, Germany, 2021.

28. LumaSense Technologies. Luxtron m920 Serie; LumaSense Technologies: Santa Clara, CA, USA, 2021.

29. Rigol Technologies, Inc. RSA3000E Series Real-Time Spectrum Analyzer; Rigol Technologies, Inc.: Puchheim, Germany, 2021.

30. Rohde \& Schwarz GmbH \& Co. KG. RES®ZVL Vector Network Analyzers; Rohde \& Schwarz GmbH \& Co. KG: München, Germany, 2021.

31. Keysight Technologies. N1501A Dielectric Probe Kit 10 MHz to 50 GHz; Keysight Technologies: Frankfurt am Main, Germany, 2021. 
32. Fallahi, H.; Sebek, J.; Prakash, P. Broadband Dielectric Properties of Ex Vivo Bovine Liver Tissue Characterized at Ablative Temperatures. IEEE Trans. Biomed. Eng. 2021, 68, 90-98. [CrossRef]

33. Lopresto, V.; Pinto, R.; Lovisolo, G.A.; Cavagnaro, M. Changes in the dielectric properties of bovine liver during microwave thermal ablation at $2.45 \mathrm{GHz}$. Phys. Med. Biol. 2012, 57. [CrossRef] [PubMed]

34. Ji, Z.; Brace, C.L. Expanded modeling of temperature-dependent dielectric properties for microwave thermal ablation. Phys. Med. Biol. 2011, 56. [CrossRef] [PubMed]

\section{Short Biography of Authors}

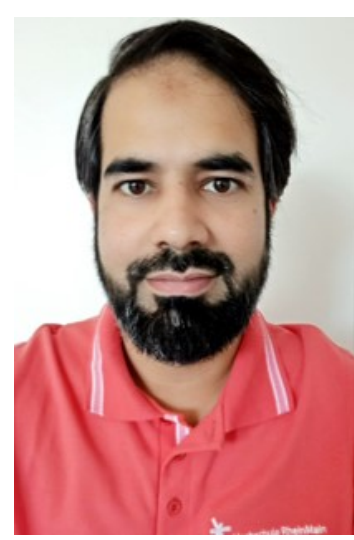

Muhammad Saad Khan received his M.Sc. in Electrical Engineering from National University of Sciences and Technology (NUST), Islamabad in 2016. He worked as a research assistant for antenna development in Research Institute for Microwave and Millimeter-Wave Studies (RIMMS), Islamabad from 2016 to 2017. He also worked as a senior RF deisgn engineer in RWR (Private) limited, Islamabad from 2017-2018. Since 2018, he is with RheinMain University of Applied Sciences as scientific research staff where he is working on monitoring of microwave ablation process. He is also enrolled as a Ph.D. candidate in Otto von Guericke University (OVGU), Magdeburg from 2019.

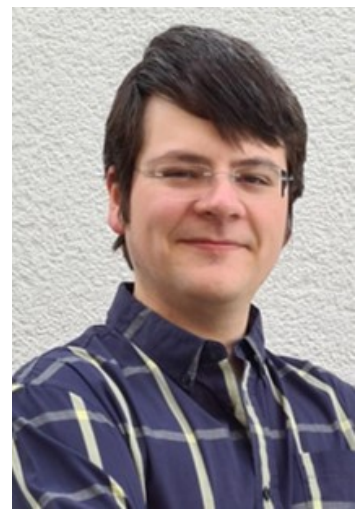

Michael Hawlitzki has been a student at RheinMain University of Applied Sciences since 2015. He received bachelor in Physical Engineering degree in 2020. Currently, he is enrolled in master program in Medical Engineering. He has been engaged with the topic of microwave ablation since last three years at Prof. Dr. A. Brensing's laboratory of Medical Measurement and Signal Processing where he completed his Bachelor's internship and thesis and now he is working on his Master's thesis on microwave ablation.

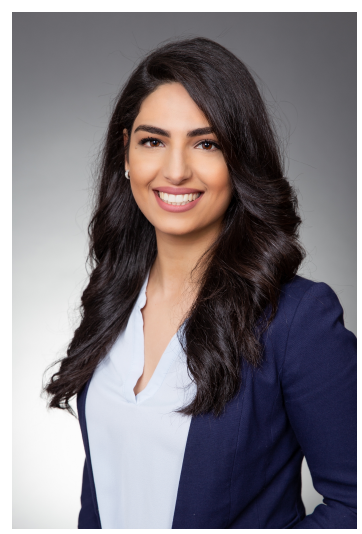

Shadan Mofrad Taheri was born in Teheran, Iran. She moved with her parents and her brother to Germany in 2005. She received the secondary school qualification from Albert-Einstein-School, in 2010 and the technical college entrance qualification, in 2015. In the same year she started her studies at RheinMain University of Applied sciences in Rüsselsheim. She graduated with a B.Eng in interdisciplinary engineering, majoring in medical Engineering, in 2019. She is currently pursuing her M.Sc. in medical engineering at the same university. Her research activities are devoted to microwave theory and technique. Currently she is working on her master's thesis on ex-vivo investigation of microwave ablation on bovine liver. 


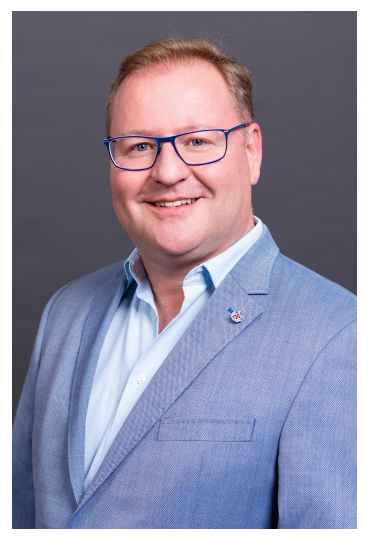

Bernd Schweizer Prof. Dr. Bernd Schweizer. Physics diploma and PhD at Technical University Darmstadt. Researcher at Philips Corporate Research and product manager at Siemens Healthineers. Research interests: Radiation transport, medical image formation, machine learning in radiology, image-guided radiotherapy. Professor of biomedical technology/medical imaging at HSRM since 2016.

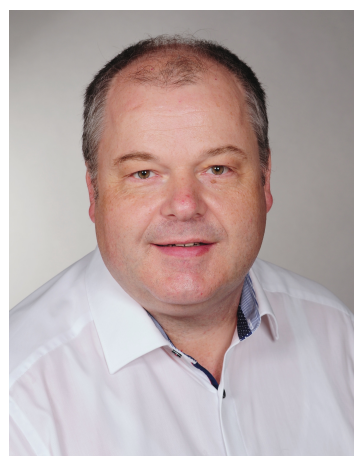

Andreas Brensing Prof. Dr. Andreas Brensing. Diploma in Electrical Engineering at RWTH Aachen and PhD at Technical University Hamburg-Harburg. Founder and $\mathrm{CEO}$ of Cardiosignal GmbH. Professor of medical device technology at HSRM since 2008. 